\title{
Androlaelaps marmosops (ACARI: LAELAPIDAE), A NEW SPECIES ASSOCIATED WITH THE MOUSE OPOSSUM, Marmosops incanus (LUND, 1840) IN THE ATLANTIC FOREST OF RIO DE JANEIRO STATE, BRAZIL
}

\author{
MARTINS-HATANO, F., ${ }^{1}$ GETTINGER, D. ${ }^{2}$ and BERGALLO, H. G. ${ }^{1}$ \\ ${ }^{1}$ Setor de Ecologia, Instituto de Biologia, Universidade do Estado do Rio de Janeiro, Rua São Francisco Xavier, \\ 524, CEP 20559-900, Rio de Janeiro, RJ, Brazil \\ ${ }^{2}$ Department of Biology, University of Central Arkansas, Conway, Arkansas, USA \\ Correspondence to: Helena Godoy Bergallo, Setor de Ecologia, Instituto de Biologia, Universidade do Estado do Rio \\ de Janeiro, Rua São Francisco Xavier, 524, CEP 20559-900, Rio de Janeiro, RJ, Brazil, e-mail: bergallo@uerj.br \\ Received August 18, 2000 - Accepted November 27, 2000 - Distributed November 30, 2001
}

(With 2 figures)

\begin{abstract}
Androlaelaps marmosops, a new species of laelapid mite, is described from the pelage of the mouse opossum, Marmosops incanus (Lund, 1840) (Mammalia: Didelphidae), in two areas of Atlantic Forest of Rio de Janeiro State. Measurements and illustrations are included for females only.
\end{abstract}

Key words: Acari, Laelapidae, Brazil, Atlantic Forest, taxonomy, marsupial.

\section{RESUMO}

Androlaelaps marmosops (Acari: Laelapidae), uma nova espécie associada à cuíca, Marmosops incanus (Lund, 1840), na Mata Atlântica do Estado do Rio de Janeiro, Brasil

Androlaelaps marmosops, uma nova espécie de ácaro lelapídeo, é descrita associada à pelagem da cuíca, Marmosops incanus (Lund, 1840) (Mammalia: Didelphidae), em duas áreas de Mata Atlântica do Estado do Rio de Janeiro. As medidas e as ilustrações foram feitas apenas para as fêmeas.

Palavras-chave: Acari, Laelapidae, Brasil, Mata Atlântica, taxonomia, marsupial.

\section{INTRODUCTION}

During ecological studies in two areas of Atlantic Forest, a new mite of the genus Androlaelaps Berlese was found in the fur of the mouse opossum, Marmosops incanus (Lund, 1840). One of these localities was on Ilha Grande, an island just off the coast of Rio de Janeiro, at the CEADS/ UERJ, Centro de Estudos Ambientais e Desenvolvimento Sustentável $\left(23^{\circ} 05^{\prime} \mathrm{S} ; 4^{\circ} 12^{\prime} \mathrm{W}\right)$, municipality of Angra dos Reis, RJ; the other locality was on the mainland, in Serrinha do Alambari ( $\left.22^{\circ} 23^{\prime} \mathrm{S} ; 44^{\circ} 32^{\prime} \mathrm{W}\right)$, municipality of Itatiaia, RJ.

The cosmopolitan genus Androlaelaps Berlese is associated with the fur and nests of many species of mammals and, occasionally, of birds (Radovsky, 1994). The genus is very poorly known in the neotropics; the wide geographical distribution and morphological variation of some species, i.e., A. fahrenholzi (Berlese) and A. rotundus (Fonseca), indicate that they may represent complexes (Furman, 1972; Gettinger \& Owen, 2000); many other unique species remain to be formally described.

Very little information is available on the laelapid mites associated with neotropical marsupials (Gettinger, 1997). Androlaelaps hirsuta Furman, A. tuberans Furman, and A. cuicensis Gettinger were also described from marsupials, and share some important characteristics with the new species described here. Guitton et al. (1986) report 
Androlaelaps guimaraesi (Fonseca) from Marmosops incanus on Ilha Grande, but we did not encounter this species in our studies. Samples of mites from the two areas were collected, fixed in $70 \%$ alcohol, and specimens were then mounted in Hoyer's medium on slides and examined with a microscope for analyses and taxonomic identification. Female mites predominated in the samples and there was not a sufficient number of males and nymphs to describe their life history stages. Eggs were found inside the opisthosoma of some female mites, but no larvae or nymphs were seen. This mite appears to be oviparous, differing from other laelapids mites associated with neotropical small mammals, like Laelaps e Gigantolaelaps, in which larvae and nymphs could be seen in the opisthosoma of the females.

We follow the concept of the genus Androlaelaps advanced by Till (1963), and use the system of setal nomenclature developed by Lindquist \& Evans (1965). The measurements are in micrometers $(\mu \mathrm{m})$ and expressed as: range, mean $\pm \mathrm{SE}$, $\mathrm{n}$. The holotype and paratypes are deposited in the Museu Nacional do Rio de Janeiro (National Museum of Rio de Janeiro), Rio de Janeiro State, Brazil. Additional paratypes will be deposited in other collections. The host type specimen, and voucher specimens of Marmosops incanus are also housed in the Museu Nacional do Rio de Janeiro, Rio de Janeiro State, Brazil.

\section{Androlaelaps marmosops, NEW SPECIES}

\section{Diagnosis}

The female is strongly distinguished from other neotropical species of the genus Androlaelaps by the following characteristics: 1 . dorsal setae long and strong, $\mathrm{j} 5$ exceeding $\mathrm{z} 5$, reaching beyond insertion of $\mathrm{j} 6 ; 2$. sternal setae I inflated basely, not reaching beyond the insertion of sternal setae II; 3. proximal setae coxa I spur-like, inflated at base, with acuminate tips; and 4. pilus dentilis inflated.

\section{Dorsum}

Dorsal shield (Fig. 1) entire, length 700-780 $\mu \mathrm{m}(729 \pm 20.2, \mathrm{n}=21)$, width at midlevel 400$480 \mu \mathrm{m}(436 \pm 19.8, \mathrm{n}=21)$, with 39 pairs of stable setae, series $\mathrm{j} / \mathrm{J}$ and $\mathrm{z} / \mathrm{Z}$ complete, with unpaired accessory setae within $\mathrm{J}$ and $\mathrm{Z}$ series of central opisthonotum; dorsal setae long and strong, j5 (82$118 \mu \mathrm{m}, 105 \pm 7.4, \mathrm{n}=21)$ and $\mathrm{z} 5(100-118 \mu \mathrm{m}$, $107 \pm 4.7, \mathrm{n}=21$ ), glands and pores as in Fig. 1 , with typical lyrifissures posterior to $\mathrm{z} 1$, prominent circular glands along margin of shield.

\section{Venter}

Tritosternum bipartite, with undivided base and pilose laciniae; presternum reticulate and weakly sclerotized; sternal shield discernibly wider $(166-188 \mu \mathrm{m}, 172.56 \pm 4.62, \mathrm{n}=25)$ than long $(135-148 \mu \mathrm{m}, 141.76 \pm 3.56, \mathrm{n}=25)$; anterior border convex, posterior border lightly concave; with reticulate-lineate surface pattern; sternal setae strong, with swollen bases; second pair of sternal setae longer than first sternal setae $(38-45 \mu \mathrm{m}, 41.0$ $\pm 2.28, \mathrm{n}=26)$, third sternal setae $(61-81 \mu \mathrm{m}, 69.61$ $\pm 6.12, \mathrm{n}=26)$ or metasternal setae $(48-59 \mu \mathrm{m}$, $51.52 \pm 2.84, \mathrm{n}=25$ ); first two pairs of lyrifissures on the sternal shield as in Fig. 2a, third pair of lyrifissures medial to metasternal setae in the integument, posterior to sternal shield. Genital shield linguiform, extending posterior to genital setae (Fig. $2 b)$. Anal shield subtriangular equilateral in shape, greatest width $(88-122 \mu \mathrm{m}, 106.00 \pm 9.10, \mathrm{n}=20)$, and length $(88-105 \mu \mathrm{m}, 98.43 \pm 3.84, \mathrm{n}=21)$; paranal setae $(56-78 \mu \mathrm{m}, 690 \pm 4.70, \mathrm{n}=19)$; postanal setae $(80-93 \mu \mathrm{m}, 85.30 \pm 4.70, \mathrm{n}=19)$. Cribrum with 3 rows of denticles, extending laterally and anteriorly at level of postanal setae (Fig. 2c). Stigma located between coxae III and IV, with peritreme extending anteriorly to the anterior half of coxa II, peritremal plate extending posteriorly to the stigma. Metapodal plates are minute, associated with the lateral margin of the genital shield.

\section{Gnathossoma}

Epistome simple, membranous. Chelicerae (Fig. 2d) of medium thickness when compared with other species of the genus: first segment as long as the second segment (without the chela); chela dentate; fixed digit slightly curved with two thornlike processes pointing ventrally; dorsal setae inflated basally, extending beyond anterior lyrifissure; pilus dentilis expanded basally, with terminal sharpened hook; moveable digit strongly curved with two thorny processes; arthrodial processes form a simple crown. 


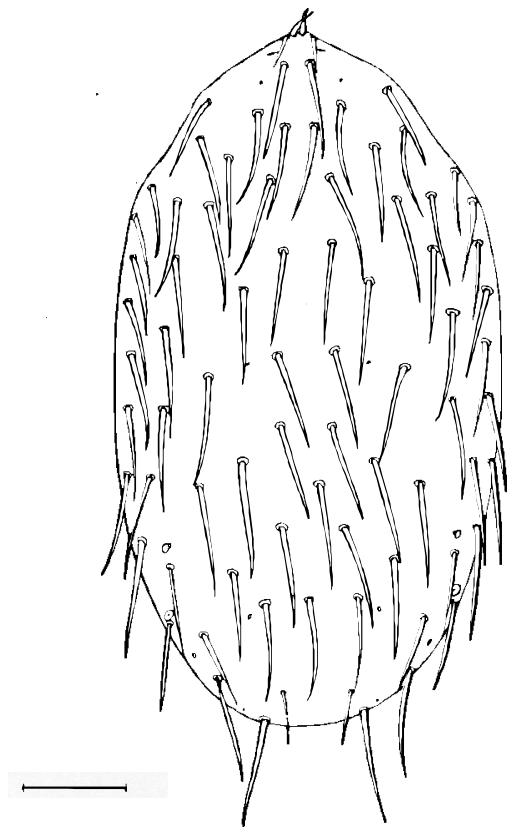

Fig. 1 - Dorsal shield of female Androlaelaps marmosops (scale bar, $100 \mu \mathrm{m}$ ).

Ventral chaetotaxy normal for genus, capitular setae $(33.00 \pm 2.30, \mathrm{n}=21)$ shorter than inner hypostomal setae $(51.00 \pm 2.80, \mathrm{n}=21)$; corniculi developed but weakly sclerotized; deutosternum with six transverse rows of two or three denticles.

\section{Legs}

Pedipalps normal, tarsus with two-tined palpal apotele. Coxa I with proximal setae simple (30$45 \mu \mathrm{m}, 40.00 \pm 3.30, \mathrm{n}=21)$ spiniform, with acuminate tips (Fig. 2e); distal setae strongly setiform, subequal to proximal setae in length (33$43 \mu \mathrm{m}, 38.00 \pm 2.60, \mathrm{n}=21)$. Papal apotele forked. Chaetotaxy normal for genus (Table 1); pv2 of trochanter I acuminate and spiniform.

\section{Type material}

Holotype: female (MN 12601) ex. Marmosops incanus (Lund, 1840), Serrinha do Alambari, municipality of Itatiaia, Estado do Rio de Janeiro, Brazil, collected 17/7/1997 by Helena de Godoy Bergallo. Holotype and paratypes were deposited in the arachnid collection of the Museu Nacional do Rio de Janeiro. Host voucher specimen HGB 57 (MN 48009) is in mammal collection of the Museu Nacional do Rio de Janeiro. a

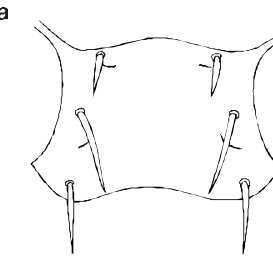

d

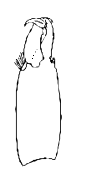

b

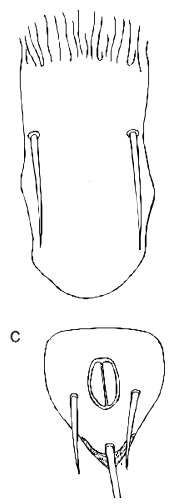

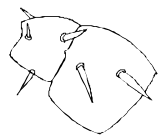

Fig. 2 - Ventral shields, coxa 1 and chelicera, female $A n$ drolaelaps marmosops (scale bar, 100mm): a) sternal shield; b) genital shield; c) anal shield; d) chelicera; e) coxa 1

Paratypes: female (MN 12602) collected on M. incanus, specimen HGB 57 (MN 48009); four females (MN 12603, MN 12604, MN 12605, MN 12606) collected on HGB \# Mi 1; one female (MN 12607) collected on HGB \# Mi 3; one female (MN 12608) collected on HGB \# Mi 4; all from the same locality as the holotype.

Etymology: the species epithet refers to the genus of the host, Marmosops.

Distribution: known only from the type locality (Serrinha do Alambari, municipality of Itatiaia, Rio de Janeiro State, Brazil) and from Ilha Grande (municipality of Angra dos Reis, Rio de Janeiro State, Brazil).

Acknowledgments - We thank C. F. D. Rocha, J. L. F. Luque, M. V. Vieira, M. A. S. Alves, and A. Peracchi for helpful comments on the manuscript. We thank P. Volpato, W. London, and G. London from Serrinha do Alambari, the coordinator of the CEADS/UERJ, C. F. D. Rocha, and the administrative coordinator of CEADS/UERJ, J. C. Dansinger, for local support. We thank K. C. Larson from the University of Central Arkansas who made many facilities available at the University and at her home, when FMH was preparing the slides. During the development of this study, FMH received a graduate fellowship from $\mathrm{CNPq}$ and $\mathrm{HGB}$ received a research grant from CNPq. This study is a portion of the results of the "Ecology, Conservation and Management of South-eastern Brazilian Ecosystems Program" and of the South-eastern Brazilian Vertebrate Ecology Project, both of the Setor de Ecologia, UERJ. 


\section{TABLE 1}

Chetotaxy of legs for Androlaelaps marmosops n. sp. collected on the fur of Marmosops incanus, in Serrinha do Alambari, Itatiaia, RJ.

\begin{tabular}{|c|c|c|c|c|}
\hline Legs & I & II & III & IV \\
\hline Coxa & 2 & 2 & 2 & 1 \\
\hline Trochanter & 6 & 5 & 5 & 5 \\
\hline Femur & 13 & 11 & 6 & 6 \\
\hline Genu & 13 & 11 & 9 & 10 \\
\hline Tibia & 13 & 10 & 8 & 10 \\
\hline
\end{tabular}

\section{REFERENCES}

FURMAN, D. P., 1972, Laelapid mites (Laelapidae: Laelapinae) of Venezuela. Brigham Young Univ. Sci. Bull. Biol. Ser., 27: 1-58.

GETTINGER, D., 1997, Androlaelaps cuicensis (Acari: Laelapidae), a new species associated with Monodelphis rubida (Thomas, 1899) in the gallery forests of central Brazil. Rev. Brasil. Biol., 57: 345-348.

GETTINGER, D. \& OWEN, R. D., 2000, Androlaelaps rotundus Fonseca (Acari: Laelapidae) associated with akodontine rodents in Paraguay: a morphometric examination of a pleioxenous ectoparasite. Rev. Brasil. Biol., 60: 425-434.

GUITTON, N., ARAUJO-FILHO, N. A. \& SHERLOCK, I. A., 1986, Ectoparasitas de roedores e marsupiais no ambiente silvestre de Ilha Grande, Estado do Rio de Janeiro, Brasil. Mem. Inst. Oswaldo Cruz, 81: 233-234.
LINDQUIST, E. E. \& EVANS, G. O., 1965, Taxonomic concepts in the Ascidae, with a modified setal nomenclature for the idiosoma of the Gamasina (Acarina: Mesostigmata). Mem. Ent. Soc. Can., 47: 1-64.

RADOVSKY, F. J., 1994, The evolution of parasitism and the distribution of some dermanyssoid mites (Mesostigmata) on vertebrate hosts. In: M. A. Houck (ed.), Mites: ecological and evolutionary analyses of life-history patterns. Chapman \& Hall, London, pp. 186-217.

TILL, W. M., 1963, Ethiopian mites of the genus Androlaelaps Berlese s. lat. Bull. Brit. Mus. (Nat. Hist.) Zool., 10: 1-104. 